[Regular Paper]

\title{
Hydrodesulfurization of Dibenzothiophene Catalyzed by Supported Metal Carbonyl Complexes (Part 6) Effects of Supports on Activities of HDS Catalysts Prepared from Supported Ruthenium Carbonyl-Cesium Hydroxide Systems
}

\author{
Atsushi Ishihara*, Masatoshi Nomura, Kenji Shirouchi, \\ and Toshiaki KABE \\ Dept. of Applied Chemistry, Faculty of Technology, Tokyo University of \\ Agriculture \& Technology, Nakacho, Koganei, Tokyo 184
}

(Received April 16, 1996)

\begin{abstract}
In hydrodesulfurization of dibenzothiophene (DBT) catalyzed by supported ruthenium carbonylcesium hydroxide systems after presulfidation, the effects of various supports such as $\mathrm{Al}_{2} \mathrm{O}_{3}, \mathrm{SiO}_{2}-\mathrm{Al}_{2} \mathrm{O}_{3}$, $\mathrm{SiO}_{2}, \mathrm{TiO}_{2}, \mathrm{NaY}$ zeolite on the catalytic activity and product selectivity were investigated. In the absence of cesium, the conversion of DBT decreased in the order $\mathrm{SiO}_{2}-\mathrm{Al}_{2} \mathrm{O}_{3}>\mathrm{Al}_{2} \mathrm{O}_{3}>\mathrm{TiO}_{2}>\mathrm{SiO}_{2}>\mathrm{NaY}$ zeolite. When cesium hydroxide was added to the catalysts derived from supported $\mathrm{Ru}_{3}(\mathrm{CO})_{12}$, the conversion of DBT increased remarkably with the use of $\mathrm{Al}_{2} \mathrm{O}_{3}, \mathrm{SiO}_{2}-\mathrm{Al}_{2} \mathrm{O}_{3}$, and $\mathrm{SiO}_{2}$ and reached the maximum values at $\mathrm{Cs} / \mathrm{Ru}=2,3$ and 2, respectively. The conversion, however, decreased in the order $\mathrm{Al}_{2} \mathrm{O}_{3}>\mathrm{SiO}_{2}>\mathrm{SiO}_{2-}$ $\mathrm{Al}_{2} \mathrm{O}_{3}$. Further addition of cesium decreased the activity. In contrast to this, when $\mathrm{NaY}$ zeolite was used, the conversion of DBT did not increase with the addition of cesium. For obtaining a high catalytic activity, it was essential to load the ruthenium hydride complex $\mathrm{Cs}\left[\mathrm{HRu}_{3}(\mathrm{CO})_{11}\right]$, obtained after reacting $\mathrm{Ru}_{3}(\mathrm{CO})_{12}$ with cesium hydroxide, onto the support. In the supported $\mathrm{Ru}_{3}(\mathrm{CO})_{12}$-cesium hydroxide systems, biphenyl was produced selectively. XP spectra showed that the addition of an appropriate amount of cesium stabilized the ruthenium sulfide on the support even under hydrogen pressure.
\end{abstract}

\section{Introduction}

To solve the recent serious air pollution in big cities, it is important to develop new catalysts for deep hydrodesulfurization (HDS) of light gas oil 1) 3). In 1980s, Pecoraro and Chianelli4) reported that ruthenium sulfide was the most active metal sulfide for the HDS of dibenzothiophene (DBT) among the transition metal sulfides. From then, much attention has been focused over the last decade on HDS catalyzed by ruthenium sulfide to develop a new generation of catalysts with different properties from the present Mo and W-based ones ${ }^{5)}$ 12)

If ruthenium sulfide could be finely dispersed on such supports with high surface areas as alumina, silica, silica-alumina, zeolite, the catalytic activity per ruthenium atom would increase, and this

\footnotetext{
* To whom correspondence should be addressed.
}

approach will be effective from the economical point of view. Some research groups have already tried HDS catalyzed by supported ruthenium sulfide using carbon ${ }^{7)}$, alumina ${ }^{8)}$, and zeolite $\left.{ }^{8 \mathrm{a})}, 10\right), 11$. However, the HDS activity of these catalysts was rather low compared with the conventional Co$\mathrm{Mo} / \mathrm{Al}_{2} \mathrm{O}_{3}$ and $\mathrm{Ni}-\mathrm{Mo} / \mathrm{Al}_{2} \mathrm{O}_{3}$ because sulfidation of the ruthenium species was incomplete, and $\mathrm{RuS}_{2}$ on alumina was unstable in hydrogen atmosphere. Furthermore, the HDS reactions were performed under atmospheric pressure, and the activities of the catalysts derived from supported ruthenium in a pressurized flow system ${ }^{9}$ have not yet been ascertained in comparison with the activities of $\mathrm{Co}-\mathrm{Mo} / \mathrm{Al}_{2} \mathrm{O}_{3}$ and $\mathrm{Ni}-\mathrm{Mo} / \mathrm{Al}_{2} \mathrm{O}_{3}$.

Recently, we have reported that the catalysts derived from supported anionic molybdenum and ruthenium carbonyls are more active in the HDS of DBT than conventional supported catalysts and those catalysts derived from supported neutral 
metal carbonyls $\left.{ }^{13)}, 14\right)$. It was shown that the use of supported anionic metal carbonyls inhibited the sintering and sublimation of metal species and maintained the dispersion of metal sulfide on the support. In the course of our study, we have become interested in the activity of supported ruthenium carbonyls in the HDS of DBT. Further, when the HDS of DBT catalyzed by alkalipromoted ruthenium catalysts was investigated in a pressurized flow reactor, it was found that addition of alkali metal remarkably increased the activities of the ruthenium catalysts and that cesium-promoted catalysts revealed activities comparable to the activity of $\mathrm{Co}-\mathrm{Mo} / \mathrm{Al}_{2} \mathrm{O}_{3}{ }^{15}$.

In the present study, the effects of supports on the activity and product selectivity in the HDS of DBT were investigated for supported ruthenium carbonyl-cesium hydroxide systems. It was found that, in the presence of cesium, the aluminasupported catalyst revealed the highest activity while silica-alumina supported one revealed the highest activity in the absence of cesium. XPS measurements showed that the addition of an appropriate amount of cesium stabilized ruthenium sulfide on the support even under hydrogen pressure.

\section{Experimental}

\section{1. Materials}

Commercially available $\mathrm{Ru}_{3}(\mathrm{CO})_{12}, \mathrm{CsOH} \cdot \mathrm{H}_{2} \mathrm{O}$ and xylene (Kishida Chemicals) were used without further purification. Tetrahydrofuran (THF) was distilled from sodium benzophenone ketyl. Alumina was gamma-alumina supplied by Japan Ketjen Co., Ltd. $\left(260 \mathrm{~m}^{2} / \mathrm{g}\right)$ which was crushed and screened to provide 0.84 - to 1.19 -mm granules used in this work. $\mathrm{SiO}_{2}-\mathrm{Al}_{2} \mathrm{O}_{3}$ (JRC-SAL2: $560 \mathrm{~m}^{2} / \mathrm{g}$; $\mathrm{Si} / \mathrm{Al}=5.3), \quad \mathrm{SiO}_{2} \quad\left(J R C-\mathrm{SIO} 4: \quad 347 \mathrm{~m}^{2} / \mathrm{g}\right), \quad \mathrm{TiO}_{2}$ (JRC-TIOl: $70.8 \mathrm{~m}^{2} / \mathrm{g}$ ), NaY zeolite (JRC-Z-Y4.8: $670 \mathrm{~m}^{2} / \mathrm{g}$ ) were supplied by the Catalysis Society of Japan. These supports were dried under vacuum at $350^{\circ} \mathrm{C}$ for $4 \mathrm{~h}$ prior to use and stored in $\mathrm{Ar}$ atmosphere. Hydrogen (99.99\%) was obtained from Tohei Chemicals. Hydrogen sulfide in hydrogen $\left(\mathrm{H}_{2} \mathrm{~S} 3 \%\right)$ was obtained from Takachio Chemicals.

\section{2. Catalyst Preparation}

\section{2. 1. $\mathrm{Ru}_{3}(\mathrm{CO})_{12} /$ Support}

$0.084 \mathrm{~g}$ of $\mathrm{Ru}_{3}(\mathrm{CO})_{12}$ was dissolved in THF. $0.46 \mathrm{~g}$ of support was added to the solution and stirred for $2 \mathrm{~h}$. The solvent was removed in vacuo.

\section{2. 2. $\mathrm{Ru}_{3}(\mathrm{CO})_{12}-m \mathrm{CsOH} /$ Support}

$0.13 \mathrm{mmol}$ of a ruthenium carbonyl $\left(\mathrm{Ru}_{3}(\mathrm{CO})_{12}\right.$, $0.084 \mathrm{~g}$ ) and $0.40-1.2 \mathrm{mmol}$ of cesium hydroxide were dissolved in methanol $(5 \mathrm{ml})$ and stirred at $25^{\circ} \mathrm{C}$ for $30 \mathrm{~min}$. After the reaction, $0.46 \mathrm{~g}$ of support was added to the reaction mixture and stirred for $2 \mathrm{~h}$. Solvent was removed in vacuo.

\section{3. Apparatus and Reaction Procedures}

A catalyst precursor was placed in a pressurized fixed-bed flow reactor $(10 \mathrm{~mm}$ i.d. $\times 300 \mathrm{~mm})$, heated at $5^{\circ} \mathrm{C} / \mathrm{min}$ and presulfided at $300^{\circ} \mathrm{C}$ under a flow of $\mathrm{H}_{2} \mathrm{~S}$ in $\mathrm{H}_{2}\left(\mathrm{H}_{2} \mathrm{~S} 3 \%\right)$ for $3 \mathrm{~h}$. After the treatment, the reactor was pressurized with hydrogen. Then, the solution containing DBT was supplied with a feed pump (Kyowa Seimitsu KHD-16). The HDS of DBT was carried out under the following conditions: temperature, $300^{\circ} \mathrm{C} ; 50 \mathrm{~kg} / \mathrm{cm}^{2} ; \mathrm{H}_{2}$ $18 \mathrm{l} / \mathrm{h}$; WHSV, $16.5 \mathrm{~h}^{-1}$; concentration of DBT in xylene, $1.0 \mathrm{wt} \%$; catalyst, $0.5 \mathrm{~g}$; Ru, $8 \mathrm{wt} \%$. The weight of the catalyst included the weights of metal and support. Conversion of DBT reached a steady state within about $3 \mathrm{~h}$. Samples of products were then collected from a gas-liquid separator four times per hour. No sign of catalyst deactivation was observed during the $10 \mathrm{~h}$ run.

\section{4. Analytical}

Reaction products were analyzed using a gas chromatography provided with an FID detector (Shimadzu GC-9A) using a G-100 column (1.2 mm i.d., film thickness $1.0 \mu \mathrm{m}$, and length $40 \mathrm{~m}$ ) supplied from Chemicals Inspection \& Testing Institute or an OV-1 capillary column $(0.25 \mathrm{~mm}$ i.d. $\times 50 \mathrm{~m})$.

\section{5. Infrared Measurement}

FTIR spectra of catalyst precursors were recorded on FT/IR-5300, Japan Spectroscopic Co., Ltd.

\section{6. XPS Measurement}

After the HDS reaction, XP spectra of the sampled catalyst were measured without exposing the catalyst to air. Each sample was mounted on a sample holder with a commercially available conducting tape. The XPS was recorded on a Shimadzu ESCA-850 photoelectron spectrometer using $\mathrm{Mg} \mathrm{K}_{\alpha}$ radiation. Before the XPS measurements, etching, i.e. sputtering by argon ion, was carried out by an ion gun equipped with ESCA-850 to obtain a clean surface (conditions: $2 \mathrm{kV}, 20 \mathrm{~mA}$ ). Binding energies (BE) were referenced to the $\mathrm{C} 1 \mathrm{~s}$ peak at $285.0 \mathrm{eV}$. The peak areas of $\mathrm{Al} 2 \mathrm{p}, \mathrm{Si} 2 \mathrm{p}, \mathrm{S} 2 \mathrm{p}$, and $\mathrm{Ru} 3 \mathrm{p}_{3 / 2}$ were determined by using the quantitative analysis and curve fitting programs included in ESCA-850.

\section{Results and Discussion}

\section{1. Effects of the Supports on the Hydrodesul- furization Activities of the Catalysts Derived from Supported Ruthenium Carbonyls}

In the HDS of DBT catalyzed by supported ruthenium carbonyl-cesium hydroxide systems 
Table 1 Hydrodesulfurization of Dibenzothiophene Catalyzed by Supported Ruthenium Carbonyl Systems ${ }^{a}$

\begin{tabular}{|c|c|c|c|c|c|}
\hline Run & Catalyst & $\begin{array}{c}\text { Conv. of DBT } \\
{[\%]}\end{array}$ & $\begin{array}{c}\text { Conv. of DBT to BP } \\
{[\%]}\end{array}$ & $\begin{array}{c}\text { Conv. of DBT to } \mathrm{CHB} \\
{[\%]}\end{array}$ & $\begin{array}{c}\text { Selectivity for BP } \\
{[\%]}\end{array}$ \\
\hline 1 & $\mathrm{Ru}_{3}(\mathrm{CO})_{12} / \mathrm{Al}_{2} \mathrm{O}_{3}$ & 44 & 38 & 6 & 86 \\
\hline 2 & $\mathrm{Ru}_{3}(\mathrm{CO})_{12} / \mathrm{SiO}_{2}-\mathrm{Al}_{2} \mathrm{O}_{3}$ & 62 & 36 & 22 & 57 \\
\hline 3 & $\mathrm{Ru}_{3}(\mathrm{CO})_{12} / \mathrm{SiO}_{2}$ & 26 & 17 & 9 & 64 \\
\hline 4 & $\mathrm{Ru}_{3}(\mathrm{CO})_{12} / \mathrm{NaY}$ zeolite & 17 & 12 & 5 & 70 \\
\hline 5 & $\mathrm{Ru}_{3}(\mathrm{CO})_{12} / \mathrm{TiO}_{2}$ & 33 & 22 & 11 & 65 \\
\hline
\end{tabular}

a) Reaction temp. $300^{\circ} \mathrm{C}$; pressure $50 \mathrm{~kg} / \mathrm{cm}^{2}$; WHSV $16.5 \mathrm{~h}^{-1}$; cat. $0.50 \mathrm{~g} ; \mathrm{H}_{2} 18 \mathrm{l} / \mathrm{h}$; initial concentration of DBT $1.0 \mathrm{wt} \%$; presulfided by $\mathrm{H}_{2} \mathrm{~S}$ in $\mathrm{H}_{2}$ at $300^{\circ} \mathrm{C}\left(\mathrm{H}_{2} \mathrm{~S} 3 \%\right)$ for $3 \mathrm{~h}$.

Table 2 Hydrodesulfurization of Dibenzothiophene Catalyzed by $\mathrm{Ru}_{3}(\mathrm{CO})_{12}-n \mathrm{CsOH} / \mathrm{Al}_{2} \mathrm{O}_{3}, \mathrm{SiO}_{2}-\mathrm{Al}_{2} \mathrm{O}_{3}$ and $\mathrm{SiO}_{2} \mathrm{Systems}$ and Characterization of the Catalysts by Means of XPS

\begin{tabular}{|c|c|c|c|c|c|c|c|}
\hline \multirow[b]{2}{*}{ Run } & \multirow[b]{2}{*}{ Activation condition } & \multicolumn{2}{|c|}{ HDS of $\mathrm{DBT}^{\mathrm{a})}$} & \multicolumn{4}{|c|}{ XPS Measurement ${ }^{\mathrm{b})}$} \\
\hline & & $\begin{array}{c}\text { Conv. of DBT } \\
{[\%]}\end{array}$ & $\begin{array}{c}\text { Selectivity for BP } \\
{[\%]}\end{array}$ & $\begin{array}{l}\mathrm{S} 2 \mathrm{p} \\
{[\mathrm{eV}]}\end{array}$ & $\begin{array}{c}\mathrm{Ru} 3 \mathrm{p}_{3 / 2} \\
{[\mathrm{eV}]}\end{array}$ & $\mathrm{Ru} / \mathrm{Al}^{\mathrm{c})}$ or $\mathrm{Ru} / \mathrm{Si}$ & $\mathrm{S} / \mathrm{R} \mathbf{u}^{\mathrm{c})}$ \\
\hline 6 & $\mathrm{Ru}_{3}(\mathrm{CO})_{12} / \mathrm{Al}_{2} \mathrm{O}_{3}$ & $44(7)$ & $86(100)$ & 162.5 & 462.1 & 0.025 & 0.45 \\
\hline 7 & $\mathrm{Ru}_{3}(\mathrm{CO})_{12}-3 \mathrm{CsOH} / \mathrm{Al}_{2} \mathrm{O}_{3}$ & $95(32)$ & $98(100)$ & 161.4 & 461.9 & 0.027 & 2.93 \\
\hline 8 & $\mathrm{Ru}_{3}(\mathrm{CO})_{12}-6 \mathrm{CsOH} / \mathrm{Al}_{2} \mathrm{O}_{3}$ & $100(41)$ & $99(100)$ & 160.5 & 462.2 & 0.016 & 7.19 \\
\hline 9 & $\mathrm{Ru}_{3}(\mathrm{CO})_{12}-9 \mathrm{CsOH} / \mathrm{Al}_{2} \mathrm{O}_{3}$ & $73(25)$ & $100(100)$ & 161.3 & 461.3 & 0.027 & 1.18 \\
\hline 10 & $\mathrm{Ru}_{3}(\mathrm{CO})_{12} / \mathrm{SiO}_{2}-\mathrm{Al}_{2} \mathrm{O}_{3}$ & $62(7)$ & $57(72)$ & 160.2 & 462.6 & 0.045 & 0.21 \\
\hline 11 & $\mathrm{Ru}_{3}(\mathrm{CO})_{12}-6 \mathrm{CsOH} / \mathrm{SiO}_{2}-\mathrm{Al}_{2} \mathrm{O}_{3}$ & $86(17)$ & $96(100)$ & 160.9 & 462.4 & 0.082 & 0.66 \\
\hline 12 & $\mathrm{Ru}_{3}(\mathrm{CO})_{12}-9 \mathrm{CsOH} / \mathrm{SiO}_{2}-\mathrm{Al}_{2} \mathrm{O}_{3}$ & $100(28)$ & $98(100)$ & 160.9 & 462.4 & 0.052 & 1.34 \\
\hline 13 & $\mathrm{Ru}_{3}(\mathrm{CO})_{12}-12 \mathrm{CsOH} / \mathrm{SiO}_{2}-\mathrm{Al}_{2} \mathrm{O}_{3}$ & $90(24)$ & $98(100)$ & 160.7 & 462.7 & 0.038 & 2.75 \\
\hline 14 & $\mathrm{Ru}_{3}(\mathrm{CO})_{12} / \mathrm{SiO}_{2}$ & $26(7)$ & $64(100)$ & 161.5 & 463.2 & 0.026 & 0.26 \\
\hline 15 & $\mathrm{Ru}_{3}(\mathrm{CO})_{12}-3 \mathrm{CsOH} / \mathrm{SiO}_{2}$ & $97(23)$ & $99(100)$ & 161.3 & 462.6 & 0.025 & 0.96 \\
\hline 16 & $\mathrm{Ru}_{3}(\mathrm{CO})_{12}-6 \mathrm{CsOH} / \mathrm{SiO}_{2}$ & $98(36)$ & $100(100)$ & 160.3 & 462.9 & 0.033 & 1.27 \\
\hline 17 & $\mathrm{Ru}_{3}(\mathrm{CO})_{12}-9 \mathrm{CsOH} / \mathrm{SiO}_{2}$ & $100(30)$ & $100(100)$ & 160.4 & 462.5 & 0.049 & 0.79 \\
\hline
\end{tabular}

a) Reaction temp. $300^{\circ} \mathrm{C}$; pressure $50 \mathrm{~kg} / \mathrm{cm}^{2}$; WHSV $16.5 \mathrm{~h}^{-1}$; cat. $0.50 \mathrm{~g} ; \mathrm{H}_{2} \mathrm{l} 8 \mathrm{l} / \mathrm{h}$; initial concentration of DBT $1.0 \mathrm{wt} \%$; data at reaction temp. $240^{\circ} \mathrm{C}$ are given in parentheses; presulfided by $\mathrm{H}_{2} \mathrm{~S}$ in $\mathrm{H}_{2}\left(\mathrm{H}_{2} \mathrm{~S} 3 \%\right)$. b) XP spectra were measured for samples used in HDS of DBT; before the measurement, the samples were sputtered by $\mathrm{Ar}^{+}$ion for 10 min; every binding energy was referenced to Carbon Cls $285.0 \mathrm{eV}$. c) The ratios of peak areas between $\mathrm{Al} 2 \mathrm{p}, \mathrm{Si} 2 \mathrm{p}, \mathrm{S} \mathrm{2p}$, and Ru $3 \mathrm{p}_{3 / 2}$ are given. Ru/Al was calculated for $\mathrm{Al}_{2} \mathrm{O}_{3}$ and $\mathrm{Ru} / \mathrm{Si}$ was calculated for $\mathrm{SiO}_{2}-\mathrm{Al}_{2} \mathrm{O}_{3}$ and $\mathrm{SiO}_{2}$.

after presulfidation, the effects of various supports such as $\mathrm{Al}_{2} \mathrm{O}_{3}, \mathrm{SiO}_{2}-\mathrm{Al}_{2} \mathrm{O}_{3}, \mathrm{SiO}_{2}, \mathrm{TiO}_{2}, \mathrm{NaY}$ zeolite on the catalytic activity and product selectivity were investigated under the following condition: $300^{\circ} \mathrm{C} ; 50 \mathrm{~kg} / \mathrm{cm}^{2} ; \mathrm{H}_{2} 18 \mathrm{l} / \mathrm{h} ; \mathrm{WHSV}, 16.5 \mathrm{~h}^{-1}$; concentration of DBT, $1.0 \mathrm{wt} \%$ in xylene; catalyst, $0.5 \mathrm{~g}$. The results obtained for the catalysts in the absence of $\mathrm{CsOH}$ are shown in Table 1. The catalysts derived from supported ruthenium carbonyls were active for HDS, and the products were biphenyl (BP) and cyclohexylbenzene (CHB) except silica-alumina. The catalytic activities of catalysts derived from supported ruthenium carbonyls decreased in the order $\mathrm{SiO}_{2}-\mathrm{Al}_{2} \mathrm{O}_{3}>\mathrm{Al}_{2} \mathrm{O}_{3}>$ $\mathrm{TiO}_{2}>\mathrm{SiO}_{2}>\mathrm{NaY}$ zeolite. When $\mathrm{SiO}_{2}-\mathrm{Al}_{2} \mathrm{O}_{3}$ was used, the sum of the yields of $\mathrm{BP}$ and $\mathrm{CHB}$ due to HDS was $58 \%$ while the total conversion of DBT was $62 \%$. The difference of $4 \%$ was due to the hydrocracking (HC) of DBT to benzene. No HC was observed for the other supports. The selectivity for $\mathrm{BP}$ decreased in the order $\mathrm{Al}_{2} \mathrm{O}_{3}>\mathrm{NaY}$ zeolite $>\mathrm{TiO}_{2}>\mathrm{SiO}_{2}>\mathrm{SiO}_{2}-\mathrm{Al}_{2} \mathrm{O}_{3} . \quad \mathrm{SiO}_{2}-\mathrm{Al}_{2} \mathrm{O}_{3}$ gave the highest yield of $\mathrm{CHB}$ and the highest total conversion of DBT. The ruthenium catalyst supported on $\mathrm{SiO}_{2}-\mathrm{Al}_{2} \mathrm{O}_{3}$ may have a higher ability to hydrogenate the aromatic ring of DBT. The tetrahydrodibenzothiophene (4-HDBT) and hexahydrodibenzothiophene (6-HDBT) formed would be easier to desulfurize than DBT because, as has been reported, the rate of HDS of 4-HDBT or 6-HDBT is 4 times higher than that of $\mathrm{DBT}^{16)}$. We have already reported that when anionic molybdenum carbonyl complexes instead of $\mathrm{Ru}_{3}(\mathrm{CO})_{12}$ are supported on $\mathrm{SiO}_{2}-\mathrm{Al}_{2} \mathrm{O}_{3}$, a higher yield of $\mathrm{CHB}$ is also obtained ${ }^{13 c), 13 d)}$.

Subsequently, the effects of the addition of cesium hydroxide on HDS using the catalysts derived from $\mathrm{Al}_{2} \mathrm{O}_{3}-, \mathrm{SiO}_{2}-\mathrm{Al}_{2} \mathrm{O}_{3} 3^{-}$, and $\mathrm{SiO}_{2}$ supported $\mathrm{Ru}_{3}(\mathrm{CO})_{12}$ systems were investigated and the results are shown in Table 2. When $\mathrm{Ru}_{3}(\mathrm{CO})_{12}$ reacted with a threefold amount of $\mathrm{CsOH}$ and then supported on alumina (run 7), the catalytic activity increased remarkably and the conversion of $\mathrm{DBT}$ at $300^{\circ} \mathrm{C}$ was $95 \%$. With the use of $\mathrm{SiO}_{2}-\mathrm{Al}_{2} \mathrm{O}_{3}$ and $\mathrm{SiO}_{2}$, the conversion of $\mathrm{DBT}$ increased to $86 \%$ at $\mathrm{Cs} / \mathrm{Ru}=2$ (n) $97 \%$ at $\mathrm{Cs} / \mathrm{Ru}=1$, respectively. During the pr/paration of the catalyst, $\mathrm{Ru}_{3}(\mathrm{CO})_{12}$ reacted with a threefold amount of cesium hydroxide to give $\mathrm{Cs}\left[\mathrm{HRu}_{3}(\mathrm{CO})_{11}\right]$ quantitatively which was confirmed by FTIR (2076(w), 


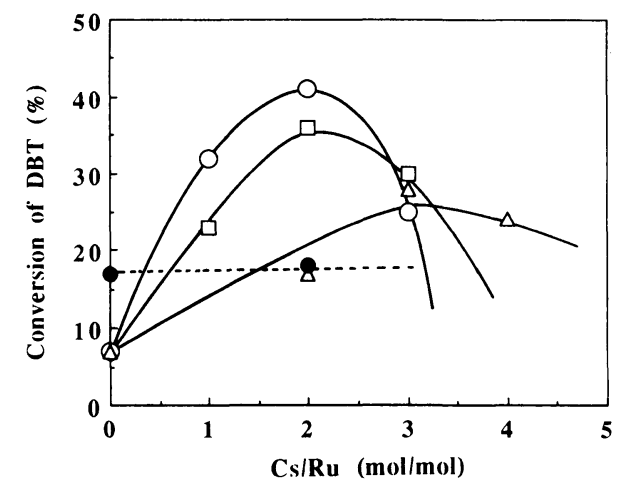

$240^{\circ} \mathrm{C}, \mathrm{O}: \mathrm{Al}_{2} \mathrm{O}_{3}, \square: \mathrm{SiO}_{2}, \triangle: \mathrm{SiO}_{2}-\mathrm{Al}_{2} \mathrm{O}_{3} ; 300^{\circ} \mathrm{C}$, zeolite. $\mathrm{Ru}_{3}(\mathrm{CO})_{12}-n \mathrm{CsOH} /$ supports; $50 \mathrm{~kg} / \mathrm{cm}^{2} ; \mathrm{H}_{2}$ $18 \mathrm{l} / \mathrm{h}$; WHSV $16.5 \mathrm{~h}^{-1}$; concentration of DBT in xylene, $1.0 \mathrm{wt} \%$; catalyst, $0.5 \mathrm{~g}$; Ru $8 \mathrm{wt} \%$.

Fig. l Effect of Supports on the Conversion of DBT

2022(vs), 1993(s), 1962(m), $1647(\mathrm{~m}$, br $) \mathrm{cm}^{-1}$ in methanol $)^{15), 17)}$. We have already reported that, when sodium hydroxide was added to aluminasupported $\mathrm{Ru}_{3}(\mathrm{CO})_{12}, \quad \mathrm{Ru}(\mathrm{acac})_{3} \quad$ (acac=acetylacetonate), and $\mathrm{RuCl}_{3}$, the catalyst derived from $\mathrm{Ru}_{3}(\mathrm{CO})_{12}-\mathrm{NaOH} / \mathrm{Al}_{2} \mathrm{O}_{3}$ was the most active among the three ${ }^{15)}$. Further, when $\mathrm{Ru}_{3}(\mathrm{CO})_{12}$ and $\mathrm{NaOH}$ were separately supported on alumina, no significant increase in the catalytic activity was observed. It was indicated that presulfidation of $\mathrm{Na}\left[\mathrm{HRu}_{3}(\mathrm{CO})_{11}\right]$ supported on alumina was essential for high catalytic activity. In the present study, the presulfidation of $\mathrm{Cs}\left[\mathrm{HRu}_{3}(\mathrm{CO})_{11}\right]$ supported on alumina is essential for high catalytic activity probably because the cesium is located close to the ruthenium on alumina.

As shown in Fig. 1 where the effects of supports on the conversion of DBT are plotted against the ratio of $\mathrm{Cs}$ and $\mathrm{Ru}$, the maximum activity was obtained at $\mathrm{Cs} / \mathrm{Ru}=2$ in the alumina-supported $\mathrm{Ru}_{3}(\mathrm{CO})_{12}-n \mathrm{CsOH}$ systems. Further addition of $\mathrm{CsOH}$ decreased the conversion of DBT (Table 2 and Fig. 1). The selectivity for BP was $100 \%$ at $240^{\circ} \mathrm{C}$ in all cesium promoted systems and more than $98 \%$ even at $300^{\circ} \mathrm{C}$. The results from $\mathrm{SiO}_{2-}$ $\mathrm{Al}_{2} \mathrm{O}_{3}$ - and $\mathrm{SiO}_{2}$-supported systems are compared with those from $\mathrm{Al}_{2} \mathrm{O}_{3}$-supported ones in Fig. 1. With the use of $\mathrm{SiO}_{2}-\mathrm{Al}_{2} \mathrm{O}_{3}$ and $\mathrm{SiO}_{2}$, the conversion of $\mathrm{DBT}$ at $240^{\circ} \mathrm{C}$ increased with the increase in the amount of cesium added and reached the maxima $28 \%$ at $\mathrm{Cs} / \mathrm{Ru}=3$ and $36 \%$ at $\mathrm{Cs} / \mathrm{Ru}=2$, respectively. The maximum value of the conversion decreased in the order $\mathrm{Al}_{2} \mathrm{O}_{3}>\mathrm{SiO}_{2}>$ $\mathrm{SiO}_{2}-\mathrm{Al}_{2} \mathrm{O}_{3}$. As opposed to this, the conversion of DBT did not increase with the addition of $\mathrm{CsOH}$ when $\mathrm{NaY}$ zeolite was used. With the use of $\mathrm{NaY}$ zeolite, it seemed that neither sodium nor cesium worked as a promoter in this catalyst system even if $\mathrm{Cs}\left[\mathrm{HRu}_{3}(\mathrm{CO})_{11}\right]$ was used as a precursor. Ruthenium sulfide might have scattered from $\mathrm{NaY}$ zeolite because the color of the used catalyst was light gray to white. When other supports than $\mathrm{NaY}$ zeolite were used, the used catalysts were always black in color which indicated the presence of ruthenium compounds. It was reported by Göbölös et al. that the activity in HDS of thiophene increased with the addition of $\mathrm{Na}_{2} \mathrm{~S}$ to ruthenium catalysts supported on KY zeolite ${ }^{11)}$. In their study, only $2 \mathrm{wt} \%$ of $\mathrm{Ru}$ was used and the $\mathrm{Na} / \mathrm{Ru}$ ratio was 1 to 2 . The amount of sodium added to the catalyst was much smaller than that used in our study. Their results, therefore, could not readily be compared with our results because such factors as the amount of ruthenium loaded, the reaction conditions, the substrate were not the same.

\section{2. XPS Measurement of the Catalysts after HDS Reaction}

XP spectra were measured for the catalysts after HDS reaction and the results are shown in Table 2. The $\mathrm{S} 2 \mathrm{p}$ and $\mathrm{Ru} 3 \mathrm{p}_{3 / 2}$ XP spectra from the supported ruthenium used for HDS showed peaks in the ranges $160.2-162.5 \mathrm{eV}$ and $461.3-463.2 \mathrm{eV}$, respectively. These results suggested that ruthenium species for most catalysts were in the oxidation state between ruthenium metal and $\mathrm{RuS}_{2}$. Although the binding energies of $\mathrm{S} 2 \mathrm{p}$ and $\mathrm{Ru} 3 \mathrm{p}_{3 / 2}$ were affected by addition of cesium, it was difficult to observe a general tendency in the changes of these binding energies with changes in support and amount of cesium. On the other hand, clear peaks of cesium were not observed for the catalysts used in the present work, indicating that most of the cesium was highly dispersed in the support and that its surface concentration was very low. For example, Fig. 2 shows $S i 2 s_{1 / 2}$ and $S 2 p$ peaks in the XPS chart of $\mathrm{Ru}_{3}(\mathrm{CO})_{12}-m \mathrm{CsOH} /$ $\mathrm{SiO}_{2}-\mathrm{Al}_{2} \mathrm{O}_{3}(m=0,6,9$ or 12$)$ where the peak of $\mathrm{Si}$ $2 \mathrm{p}_{1 / 2}$ can be used as a reference peak. Although the peaks of Cs $4 p_{1 / 2}(172 \mathrm{eV})$ and Cs $4 p_{3 / 2}$ $(162 \mathrm{eV})$ may be observed in the XPS chart, the increase in the peaks around $172 \mathrm{eV}$ could not be observed with the increased amount of cesium added. In contrast, the peak around $161 \mathrm{eV}$ increased with the increased amount of cesium added. As a result, it was considered that the peak around $161 \mathrm{eV}$ would be the peak of $\mathrm{S} 2 \mathrm{p}$ rather than that of $\mathrm{Cs} 4 \mathrm{p}_{3 / 2}$. For $\mathrm{Al}_{2} \mathrm{O}_{3}$ and $\mathrm{SiO}_{2}$, similar results were observed. Further, when these supports were used, the peak areas around $161 \mathrm{eV}$ at $\mathrm{Cs} / \mathrm{Ru}=3$ were much smaller than those at $\mathrm{Cs} / \mathrm{Ru}=2$, indicating that the contribution of $\mathrm{Cs}$ $4 \mathrm{p}_{3 / 2}$ to the peak around $161 \mathrm{eV}$ would be very slight. 

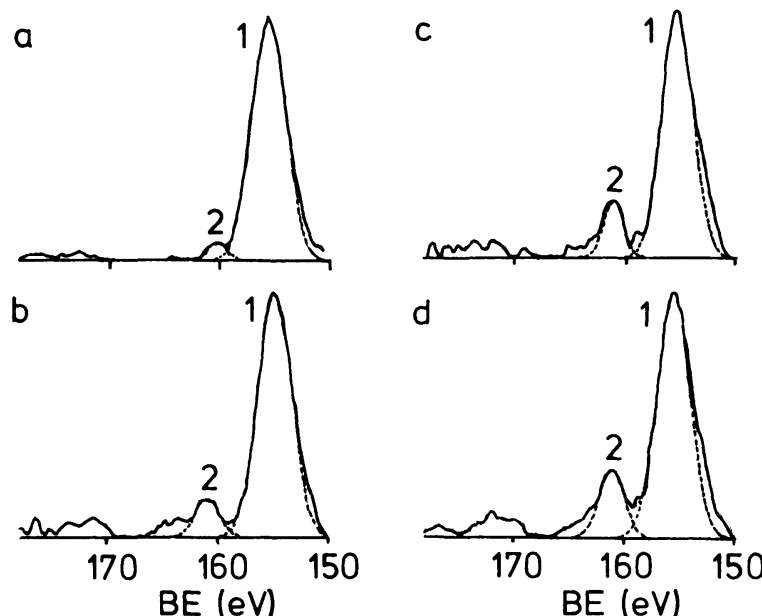

1: Si $2 \mathrm{~s}_{1 / 2} ; 2$ : S 2p, a: $m=0$; b: $m=6$; c: $m=9$; d: $m=12$ in $\mathrm{Ru}_{3}(\mathrm{CO})_{12}-m \mathrm{CsOH} / \mathrm{SiO}_{2}-\mathrm{Al}_{2} \mathrm{O}_{3}$. In each figure, the peak height of 1 was adjusted to a constant value. The peak areas of $S 2 p$ which were given by the dotted line of 2 were determined by the curve fitting treatment.

Fig. 2 Si $2 \mathrm{~s}_{1 / 2}$ and S $2 \mathrm{p}$ Peaks in the XPS Chart

The $\mathrm{Ru} / \mathrm{Al}$ or $\mathrm{Ru} / \mathrm{Si}$ and $\mathrm{S} / \mathrm{Ru}$ ratios were obtained from the peak areas of the XP spectra (Table 2). Although the values of $\mathrm{Ru} / \mathrm{Si}$ for $\mathrm{SiO}_{2}-\mathrm{Al}_{2} \mathrm{O}_{3}$ and $\mathrm{SiO}_{2}$ supported catalysts were higher than the $\mathrm{Ru} / \mathrm{Al}$ values for $\mathrm{Al}_{2} \mathrm{O}_{3}$-supported ones, some of the former catalysts showed lower catalytic activities than the latter. The result indicated that the dispersion of ruthenium species for some $\mathrm{SiO}_{2}-\mathrm{Al}_{2} \mathrm{O}_{3}$ and $\mathrm{SiO}_{2}$ supported catalysts was not so high as that of cesium promoted alumina catalysts while the bulk of the ruthenium species for $\mathrm{SiO}_{2}-\mathrm{Al}_{2} \mathrm{O}_{3}$ and $\mathrm{SiO}_{2}$ supported catalysts existed in higher concentrations. One of the most important phenomena was observed with the S/ $\mathrm{Ru}$ values which increased with the addition of cesium. When cesium was added to the aluminasupported ruthenium catalysts, the $\mathrm{S} / \mathrm{Ru}$ values increased remarkably as shown in Table 2 , indicating that the presence of cesium stabilized the ruthenium sulfide on the catalyst surface. The alumina-supported catalysts showed the maximum $\mathrm{S} / \mathrm{Ru}$ value at $\mathrm{Cs} / \mathrm{Ru}=2$. It is likely that in this catalyst system, not only the ruthenium species are sulfurized close to $\mathrm{RuS}_{2}$, but also a significant amount of the sulfur formed by the HDS reaction may accumulate on the catalyst and may have coated the ruthenium atoms, because HDS of DBT was probably much more rapid than the formation of hydrogen sulfide by the reaction of surface sulfur with hydrogen. The coating of the ruthenium atoms by large amounts of sulfur results in higher value of $\mathrm{S} / \mathrm{Ru} 3 \mathrm{p}$ and lower value of $\mathrm{Ru} 3 \mathrm{p} / \mathrm{Al}$. This lower value of $\mathrm{Ru} 3 \mathrm{p} / \mathrm{Al}$ would also reflect the

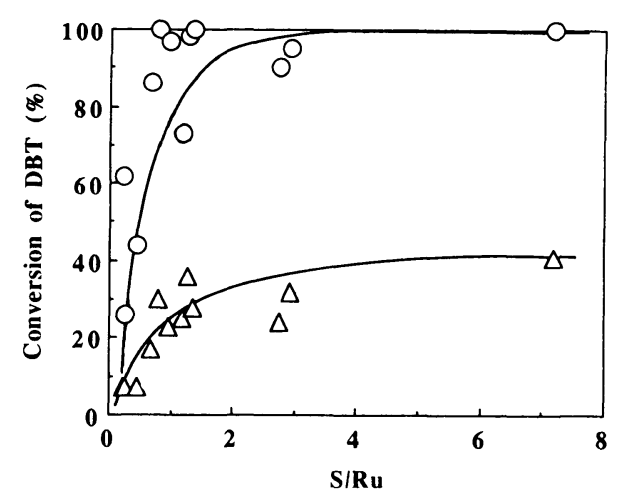

$\mathrm{Ru}_{3}(\mathrm{CO})_{12}-m \mathrm{CsOH} /$ supports: $\bigcirc 300^{\circ} \mathrm{C}, \quad \triangle 240^{\circ} \mathrm{C}$. $m=0,3,6,9$, or 12 ; supports $=\mathrm{Al}_{2} \mathrm{O}_{3}, \mathrm{SiO}_{2}-\mathrm{Al}_{2} \mathrm{O}_{3}$, or $\mathrm{SiO}_{2}$.

Fig. 3 Plots of S/Ru Ratio in XPS $v s$. Conversion of DBT

higher dispersion of ruthenium species. It is suggested that the presence of cesium would prevent ruthenium species from sintering by inhibiting the reduction of ruthenium sulfide species to ruthenium metal to maintain the higher dispersion and activity. Further addition of cesium decreased the value of $\mathrm{S} / \mathrm{Ru} 3 \mathrm{p}$ probably because HDS activity was not high and the accumulation of sulfur did not occur. It seems that the $\mathrm{S} / \mathrm{Ru}$ value may be related to the HDS activity. Similar results were observed for the addition of cesium to $\mathrm{SiO}_{2}-\mathrm{Al}_{2} \mathrm{O}_{3}$ and $\mathrm{SiO}_{2}$ supported catalysts. However, the $\mathrm{S} / \mathrm{Ru}$ values did not increase so much as in the case when cesium was added to the $\mathrm{Al}_{2} \mathrm{O}_{3}$-supported catalysts. Further, $\mathrm{SiO}_{2}-\mathrm{Al}_{2} \mathrm{O}_{3}$ supported systems did not give the maximum value of $\mathrm{S} / \mathrm{Ru}$ value in the range $\mathrm{Cs} / \mathrm{Ru}=0-4$. In this case, it seems that the contact between ruthenium and cesium was not sufficient, since the surface area of $\mathrm{SiO}_{2}-\mathrm{Al}_{2} \mathrm{O}_{3}$ is two times that of $\mathrm{Al}_{2} \mathrm{O}_{3}$. Therefore, the effects of cesium stabilizing the $\mathrm{R}-\mathrm{S}$ bonds promote $\mathrm{C}-\mathrm{S}$ bond scission and prevent ruthenium species from sintering to maintain higher dispersion and HDS activity were smaller for $\mathrm{SiO}_{2}-\mathrm{Al}_{2} \mathrm{O}_{3}$ than for $\mathrm{Al}_{2} \mathrm{O}_{3}$. The results mentioned above indicate that the values of $\mathrm{S} / \mathrm{Ru}$ and $\mathrm{Ru} / \mathrm{Al}$ or $\mathrm{Ru} / \mathrm{Si}$, which are concentrations of ruthenium and sulfur on the catalyst surface, are related to the catalytic activity. It is suggested that cesium and supports affect the HDS activity by changing the concentrations of ruthenium and sulfur on the catalyst surface, which may be related to the morphology of ruthenium sulfide on the catalyst.

To investigate the relationship between HDS activity and $\mathrm{S} / \mathrm{Ru}$, the values of $\mathrm{S} / \mathrm{Ru}$ were plotted against the conversion of DBT in Fig. 3. Figure 3 also shows the tendency that the conversion of 
DBT increases with increase in the $S / R u$ ratio. The result suggests that the catalytic activity increases when ruthenium sulfide is stabilized in the presence of cesium. Further, it seems that the presence of this promoter strengthens the bond between ruthenium and sulfur to stabilize ruthenium sulfide in which the carbon-sulfur bond scission may proceed more easily than that in the less sulfided ruthenium species close to the low valent ruthenium metal. Cesium promoted $\mathrm{Ru}_{3}(\mathrm{CO})_{12} / \mathrm{Al}_{2} \mathrm{O}_{3}$ catalysts showed the maximum value of $\mathrm{S} / \mathrm{Ru}$ at $\mathrm{Cs} / \mathrm{Ru}=2$ among the catalysts examined in this study. This may be explained by the additive effects resulted from the combined use of ruthenium, cesium, and alumina.

\section{3. The Role of Cesium}

Although HDS of thiophenes using ruthenium sulfide catalysts have been reported, the effects of addition of alkali metals on the HDS reactions are less well-known in those catalysts. It was reported that in HDS of thiophene, a ruthenium catalyst supported on $\mathrm{Na}_{2} \mathrm{~S}$-doped $\mathrm{KY}$ zeolites showed activity three times higher than that of a $\mathrm{KY}$-supported catalyst ${ }^{11)}$. It was concluded that the addition of $\mathrm{Na}_{2} \mathrm{~S}$ neutralized the $\mathrm{Br} \phi$ nsted acidity of the zeolite and thus increased the activity. In the present study, the neutralization of $\operatorname{Br} \phi$ nsted acidity of the supports also seems to be related to the increase in the HDS activity. For example, it can be assumed that $\mathrm{SiO}_{2}-\mathrm{Al}_{2} \mathrm{O}_{3}$ supported catalysts need larger amounts of added cesium than $\mathrm{Al}_{2} \mathrm{O}_{3}$ - or $\mathrm{SiO}_{2}$-supported ones to neutralize Br $\phi$ nsted acids to get the maximum activity. However, all the results obtained here cannot be explained merely by neutralization of $\mathrm{Br} \phi$ nsted acidity of the supports. For example, the effect of the addition of cesium on $\mathrm{SiO}_{2}$-supported catalysts cannot also be explained only by the neutralization of $\operatorname{Br} \phi$ nsted acidity of the supports because such neutralization is not important for $\mathrm{SiO}_{2}$. There must be something more, besides neutralization of Br $\phi$ nsted acidity of the supports, to explain the role of cesium.

In the present paper, it was clarified that the modification of $\mathrm{Ru}_{3}(\mathrm{CO})_{12}$ with cesium hydroxide improved the properties of the catalyst obtained. Ruthenium species on the catalyst which showed higher catalytic activity in the presence of cesium existed in the oxidation state close to $\mathrm{RuS}_{2}$ rather than to ruthenium metal. It was suggested that the addition of an appropriate amount of cesium stabilized $\mathrm{RuS}_{2}$ on the support even under hydrogen pressure, promoted the $\mathrm{C}-\mathrm{S}$ bond scission, and prevented the ruthenium species from sintering to maintain higher dispersion and HDS activity.

\section{Conclusions}

The effects of cesium in supported ruthenium carbonyls on HDS of DBT were investigated in order to develop and elucidate the role of cesium and the following results were obtained:

1) In the HDS of DBT catalyzed by supported ruthenium carbonyl systems in the absence of cesium, the conversion of DBT decreased in the order $\mathrm{SiO}_{2}-\mathrm{Al}_{2} \mathrm{O}_{3}>\mathrm{Al}_{2} \mathrm{O}_{3}>\mathrm{TiO}_{2}>\mathrm{SiO}_{2}>\mathrm{NaY}$ zeolite.

2) With the addition of cesium hydroxide, the conversion of DBT with the use of $\mathrm{Al}_{2} \mathrm{O}_{3-}, \mathrm{SiO}_{2}-$ $\mathrm{Al}_{2} \mathrm{O}_{3}-$, and $\mathrm{SiO}_{2}$-supported catalysts increased remarkably and reached the maximum values at $\mathrm{Cs} / \mathrm{Ru}=2,3$ and 2, respectively.

3) The maximum activity in each catalyst decreased in the order $\mathrm{Ru}_{3}(\mathrm{CO})_{12}-6 \mathrm{CsOH} / \mathrm{Al}_{2} \mathrm{O}_{3}>$ $\mathrm{Ru}_{3}(\mathrm{CO})_{12}-6 \mathrm{CsOH} / \mathrm{SiO}_{2}>\mathrm{Ru}_{3}(\mathrm{CO})_{12}-9 \mathrm{CsOH} /$ $\mathrm{SiO}_{2}-\mathrm{Al}_{2} \mathrm{O}_{3}$.

4) XP spectra showed that the addition of an appropriate amount of cesium stabilized the ruthenium sulfide on the support even under hydrogen pressure to increase the activity of HDS.

\section{Acknowledgments}

Part of this work has been carried out as a research project of The Japan Petroleum Institute commissioned by the Petroleum Energy Center with the subsidy of the Ministry of International Trade and Industry.

\section{References}

1) a) Ishihara, A., Tajima, H., Kabe, T., Chem. Lett., 669 (1992). b) Kabe, T., Ishihara, A., Tajima, H., Ind. Eng. Chem. Res., 31, 1577 (1992) and literature cited therein.

2) Kabe, T., Ishihara, A., Zhang, Q., Appl. Catal., A97, Ll (1993).

3) Ishihara, A., Itoh, T., Hino, T., Qi, P., Nomura, M., Kabe, T., J. Catal., 140, 184 (1993).

4) Pecoraro, T. A., Chianelli, R. R., J. Catal., 67, 430 (1981).

5) Lacroix, M., Boutarfa, N., Guillard, C., Vrinat, M., Breysse, M., J. Catal., 120, 473 (1989).

6) Vrinat, M., Lacroix, M., Breysse, M., Mosoni, L., Roubin, M., Catal. Lett., 3, 405 (1989).

7) a) Vissers, J. P. R., Groot, C. K., van Oers, E. M., de Beer, V. H. J., Prins, R., Bull. Soc. Chim. Belg., 93, 813 (1984). b) Ledoux, M. J., Michaux, O., Agostini, G., Panissod, P., J. Catal., 102, 275 (1986).

8) a) Harvey, T. G., Matheson, T. W., J. Catal., 101, 253 (1986). b) Mitchell, P. C. H., Scott, C. E., Bonnelle, J. P., Grimblot, J. G., J. Catal., 107, 482 (1987). c) Kuo, Y., Cocco, R. A., Tatarchuk, B. J., J. Catal., 112, 250 (1988). d) De Los Reyes, J. A., Göbölös, S., Vrinat, M., Breysse, M., Catal. Lett., 5, 17 (1990). e) De Los Reyes, J. A., Vrinat, M., Geantet, C., Breysse, M., Grimblot, J. G., J. Catal., 142, 455 (1993). f) Chary, K. V. R., Khajamasthan, S., Vijayakumar, V., J. Chem. Soc., Chem. Commun., 1339 (1989). 
9) Liaw, S.-J., Raje, A., Lin, R., Davis, B. H., ACS Prep. Div. Petrol. Chem., 636 (1994).

10) Breysse, M., Geantet, C., Lacroix, M., Portefaix, J. L., Vrinat, M., ACS Prep. Div. Petrol. Chem., 587 (1994).

$11)$ Göbölös, S., Breysse, M., Cattenot, T., Decamp, M., Lacroix, M., Portefaix, J. L., Vrinat, M., eds. by Occelli, M. L., Anthony, R. G., "Advances in Hydrotreating Catalysts," Elsevier Science Publishers B. V., Amsterdam (1989), p. 243.

12) a) Passaretti, J., Chianelli, R. R., Wold, A., Dwight, K., Covino, J., J. Solid State Chem., 64, 365 (1986). b) Bellaloui, A., Mosoni, L., Roubin, M., Vrinat, M., Lacroix, M., Breysse, M., C. R. Acad. Sci. Paris, 304, 1163 (1987).

13) a) Ishihara, A., Azuma, M., Matsushita, M., Kabe, T., Sekiyu Gakkaishi, 36, (5), 360 (1993). b) Ishihara, A., Nomura, M., Matsushita, M., Shirouchi, K., Kabe, T., "New Aspects of Spillover Effect in Catalysis," eds. by
Inui, T. et al., Elsevier Science B. V., (1993), p. $357 . \quad$ c) Ishihara, A., Shirouchi, K., Kabe, T., Chem. Lett., 589 (1993). d) Ishihara, A., Shirouchi, K., Kabe, T., Sekiyu Gakkaishi, 37, (4), 411 (1994). e) Ishihara, A., Matsushita, M., Shirouchi, K., Zhang, Q., Kabe, T., Sekiyu Gakkaishi, 39, (1), 26 (1996).

14) a) Ishihara, A., Nomura, M., Kabe, T., J. Catal., 150, 212 (1994). b) Ishihara, A., Nomura, M., Kabe, T., Sekiyu Gakkaishi, 37, (3), 300 (1994).

15) a) Ishihara, A., Nomura, M., Kabe, T., Chem. Lett., 2285 (1992). b) Ishihara, A., Nomura, M., Takahama, H., Hamaguchi, H., Kabe, T., Sekiyu Gakkaishi, 39, (3), 211 (1996).

16) Houalla, M., Nag, N. K., Sapre, A. V., Broderick, D. H., Gates, B. C., AIChE J., 24, 1015 (1978).

17) Johnson, B. F. G., Lewis, J., Raithby, P. R., Suess, G., J. Chem. Soc., Dalton Trans., 1356 (1979).

要 旨

担持金属カルボニル錯体を用いたジベンゾチオフェンの水秦化脱硫反応（第 6 報）

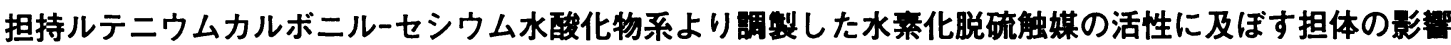

\author{
石原 篤, 野村 正敏, 城内 賢司, 加部 利明 \\ 東京農工大学工学部応用化学科, 184 東京都小金井市中町 2-24-16
}

\begin{abstract}
担持ルテニウムカルボニルー水酸化セシウム系触媒を用いた ジベンゾチオフェン（DBT）の水素化脱硫反応において, 様々 な担体 $\left(\mathrm{Al}_{2} \mathrm{O}_{3}, \mathrm{SiO}_{2}-\mathrm{Al}_{2} \mathrm{O}_{3}, \mathrm{SiO}_{2}, \mathrm{TiO}_{2}\right.$ および $\mathrm{NaY}$ zeolite $)$ の触媒活性および生成物選択性に及ほす影響を検討した。セシ ウムを用いない場合, DBT の転化率は $\mathrm{SiO}_{2}-\mathrm{Al}_{2} \mathrm{O}_{3}>\mathrm{Al}_{2} \mathrm{O}_{3}>$ $\mathrm{TiO}_{2}>\mathrm{SiO}_{2}>\mathrm{NaY}$ zeolite の順に隇少した。水酸化セシウムを 加えた触媒では, $\mathrm{SiO}_{2}-\mathrm{Al}_{2} \mathrm{O}_{3}, \mathrm{Al}_{2} \mathrm{O}_{3}$ および $\mathrm{SiO}_{2}$ を用いた場 合に触媒活性は著しく向上し，それぞれ $\mathrm{Cs} / \mathrm{Ru}=2,3$ および 2 の時に最大値に達し, その值は $\mathrm{Al}_{2} \mathrm{O}_{3}>\mathrm{SiO}_{2}>\mathrm{SiO}_{2}-\mathrm{Al}_{2} \mathrm{O}_{3}$ の順に滅少した。さらにセシウムを加えると活性は低下した。
\end{abstract}

これに対して，NaY zeoliteを用いた場合，セシウムの添加に 伴い DBT の転化率は向上しなかった。 $\mathrm{Ru}_{3}(\mathrm{CO})_{12}$ と水酸化 セシゥムとの反応により得られるルテニウムヒドリド錯体 Cs $\left[\mathrm{HRu}_{3}(\mathrm{CO})_{11}\right]$ を担体上に担持することが高活性を得るため に本質的であった。担持ルテニウムカルボニルー水酸化セシウ ム系触媒ではビフェニルが選択的に生成した。XP スペクトル を測定した結果，適当な量のセシウムの添加によって，水素加 圧下でさえ硫化ルテニウムが担体上に安定化されることが示さ れた。

\title{
Keywords
}

Hydrodesulfurization, Dibenzothiophene, Ruthenium carbonyl, Cesium hydroxide, Catalyst preparation, Supported catalyst 